\title{
PKM beras ketan hitam desa kalimas kecamatan sungai kakap kabupaten kubu raya
}

\author{
PKM Rice Ketan Black Village Kalimas Sub-district Sungai Kakap District Kubu Raya
}

\author{
Susana $^{1)}$, Evi Sofiana ${ }^{2)}$ \\ ${ }^{1}$ Pengajar JurusanTeknologi Hasil Perkebunan Politeknik Negeri Pontianak \\ ${ }^{2}$ Pengajar Jurusan Administrasi Bisnis, Politeknik Negeri Pontianak \\ Email: susana020674@gmail.com
}

Informasi Artikel:

Dikirim: 06/09/2019; ditinjau: 10/09/2019; disetujui: 30/09/2019

\begin{abstract}
The PKM partner is a farmer group in Kalimas Village, Kakap District, Kubu Raya Regency, West Kalimantan. The problems faced by partners are: 1) human resources who have knowledge and skills about processing technology for agricultural products, 2) partners have an entrepreneurial spirit, 3) expertise on appropriate technology that can be applied to entrepreneurship, and 4) Partners do not have the knowledge and applied skills in the field of business marketing. Solutions for community partnership programs include: 1) enhancing human resource knowledge and skills, 2) building entrepreneurial enthusiasm, 3) providing knowledge in theory and practice encompassing the overall expertise of appropriate technology that can be applied to entrepreneurship, and 4) provide knowledge and skills in product processing and product marketing. Output Targets; 1) knowledge and skills of human resources increase, 2) foster an entrepreneurial spirit, 3) partners have the knowledge and skills in implementing appropriate technology, 4) partners have the knowledge to manage a business management system, and 5) partners have the product marketing knowledge and skills and can implement them. The method to be applied in achieving the objectives of the activity is; 1) socialization, training and processing assistance, 2) business management training, 3) training and product marketing demonstration, 4) assistance in product marketing the results of PKM activities are partners having skills in processing black sticky rice into products that have added value and partners having motivation to develop business of processed black sticky rice
\end{abstract}

Keywords: products, processing, black sticky rice, packaging, business management, marketing

\begin{abstract}
ABSTRAK
Mitra PKM adalah kelompok tani Desa Kalimas Kecamatan Kakap Kabupaten Kubu Raya Kalimantan Barat .Masalah Mitra yang dihadapi mitra : 1) sumber daya manusia yang memiliki pengetahuan dan keterampilan tentang teknologi pengolahan hasil pertanian, 2) mitra memiliki semangat berwirausaha, 3) keahlian terhadap teknologi tepat guna yang dapat diterapkan untuk berwirausaha, dan 4) mitra belum memiliki pengetahuan dan keterampilan terapan pada bidang pemasaran usaha. Solusi program kemitraan masyarakat meliputi: 1) meningkatkan pengetahuan dan keterampilan sumber daya manusia, 2) membangun semangat berwirausaha, 3) memberikan ilmu secara teori dan praktek mencakup keahlian olah secara menyeluruh terhadap teknologi tepat guna yang dapat diterapkan untuk berwirausaha, 4) memberikan pengetahuan dan
\end{abstract}


keterampilan pada pengolahan produk dan pemasaran produk. Target luaran 1) pengetahuan dan keterampilan sumber daya manusia meningkat, 2) menumbuhkan semangat berwirausaha, 3) mitra memiliki pengetahuan dan keterampilan dalam mengimplementasikan teknologi tepat guna, 4) mitra memiliki pengetahuan untuk mengelola sistem manajemen usaha, dan 5) mitra memiliki pengetahuan dan keterampilan pemasaran produk dan dapat mengimplementasikannya. Metode yang akan diterapkan dalam mencapai tujuan kegiatan adalah; 1) sosialisasi, pelatihan dan pendampingan pengolahan, 2) pelatihan manajemen usaha, 3) pelatihan dan demonstrasi pemasaran produk, dan 4) pendampingan dalam pemasaran produk Hasil dari kegiatan PKM adalah mitra memiliki keterampilan dalam mengolah beras ketan hitam menjadi produk-produk yang memiliki nilai tambah dan mitra memiliki motivasi untuk mengembangkan usaha olahan beras ketan hitam

Kata kunci: produk, pengolahan, beras ketan hitam, pengemasan, manajemen usaha, pemasaran

\section{PENDAHULUAN}

Desa Kalimas terletak pada arah utara dari Kabupaten Kubu Raya dengan jarak tempuh $\pm 18 \mathrm{Km}$ dari Kampus Politeknik Negeri Pontianak. Secara geografis Desa Kalimas memiliki luas wilayah 4.565 ha dengan rincian Perkampungan (771 ha), Perkebunan (2185 ha), Pekarangan (239 ha), Tanah Pertanian (1370 ha), dengan luas wilayah tersebut maka masyarakat kebanyakan bekerja pada bidang pertanian. Desa Kalimas dilihat dari potensi sosial ekonominya cukup maju baik dalam bidang pertanian, industri, dan perdagangan, dari hasil potensi perkebunan yang paling banyak adalah kelapa dan padi. Produksi beras di Kabupaten Kubu Raya sendiri sampai saat ini mencapai 190.000 ton per tahun dengan luas area panen mencapai 50 ribu hektare. Hasil panen padi perdana di Kabupaten Kubu Raya cukup menggembirakan. Dari 3.000 hektare lahan di Dusun Parit Keladi II dan Desa Kalimas II menghasilkan 12 ribu ton beras (Aprin, 2012)

Tepung beras hitam (Oryza sativa L.) kaya sumber senyawa antioksidan, termasuk antosianin dan tokoferol. Antosianin, seperti cyanidin-3-Oglucoside dan peonidin-3-Oglukosida, semuanya efektif konstituen beras hitam dan mereka membantu melindungi arteri, mencegah kerusakan DNA oksidatif, dan menghambat pembentukan radikal bebas yang merusak sel (Adom dan Liu, 2002; Kong, Wang dan Cao, 2008; Kim et al.,
2010; Kim et al., 2016). Ekstrak beras hitam dipacu oleh aktivitas osteogenik (Kim et al., 2016). Pemberian ekstrak beras hitam setiap hari secara oral di $200 \mathrm{mg} / \mathrm{kg}$ selama 8 minggu mencegah penurunan kepadatan tulang (Jang et al., 2016). Banyak manfaat kesehatan yang diklaim berasal dari produk fermentasi ini (Şanlier, Gökcen dan Sezgin, 2019). Fermentasi dari mikroba produk makanan ini akan meningkatkan ketersediaan hayati pangan phytochemical dan nutrisi (Schmidt et al., 2014). Dedak beras hitam apabila difermentasi dengan jamur dan bakteri asam laktat dapat dimanfaatkan sebagai kesehatan dan obat-obatan (Lai et $a l .$, 2013) serta dapat meningkatkan mineral pada tulang dan penyerapan kalsium (Ali et al., 2009; Bertoldi, 2014; Weaver, 2015).

Beras hitam yang jenis beras khusus dengan pigmen warna telah banyak dibudidayakan dan dikonsumsi di negaranegara Asia Tenggara selama beberapa dekade karena beras hitam dicirikan oleh tingginya kandungan polifenol, khususnya anthocyanin (Lee, 2010), senyawa antioksidan lainnya, seperti sebagai flavon, proantosianidin, dan asam fenolik yang berkontribusi pada profil nutrisi sehatnya (Abdel-Aal, Young dan Rabalski, 2006). Beras hitam memiliki efek menguntungkan pada kesehatan manusia dan berkurang risiko mengembangkan penyakit kronis (Dipti et al., 2012; Samyor, Das dan Deka, 2017).

Salah satu kelompok tani di wilayah tersebut adalah kelompok tani Sinar Mulia 1 
yang dipimpin oleh Bapak Sy. Ahmadi. Aktivitas kelompok ini sehari-harinya adalah bertani padi dan berkebun kelapa. Padi merupakan komoditas yang paling dominan dibudi dayakan di Desa Kalimas. Padi yang telah dipisahkan dari sekamnya akan menghasilkan beras. Beras yang diproduksi dari tanaman padi di Desa Kalimas memiliki beberapa jenis, diantaranya beras ketan hitam yang produksinya lebih lama \pm .7 bulan. Saat ini telah dikenal beberapa jenis padi yang kaya akan antosianin, seperti beras hitam, beras merah, beras ketan hitam, dan yang lain-lain (Itani dan Ogawa, 2004; Ling dkk., 2001; Perera dan Jansz, 2000). Beras ketan hitam merupakan sumber pangan lokal yang kaya akan antosianin dan belum banyak dikembangkan sebagai pangan fungsional ( NanikSuhartatik, 2013).

Permasalahan mitra Desa Kalimas antara lain : 1) Mitra belum memiliki pengetahuan dan keterampilan serta keahlian terhadap teknologi pengolahan beras ketan hitam yang dapat diterapkan untuk berwirausaha sebagai akibat dari rendahnya kualitas SDM, 2) Mitra memiliki jiwa kewirausaahan yang tinggi, namun belum terarah menjadi usaha kecil, 3) Mitra belum memiliki pengetahuan dan keterampilan terapan pada bidang manajemen usaha, 4) Mitra belum memiliki pengetahuan dan keterampilan terapan pada bidang pemasaran produk.

\section{METODA PELAKSANAAN}

Kegiatan Pengabdian masyarakat ini dilakukan dibalai Desa Kalimas Kecamatan Kakap Kabupaten Kubu Raya, selain lokasi strategis dan kondisi jalan yang baik, pemilihan lokasi ini juga bertujuan memudahkan akses seluruh mitra yang terlibat. Peserta yang terlibat dalam kegiatan ini berjumlah 20 orang.

\section{Bahan}

Bahan utama yang digunakan adalah beras ketan hitam yang berasal dari Desa Kalimas, sedangkan bahan lainnya berasal dari beberapa toko yang ada di wilayah Kota
Pontianak. Bahan-bahan lain yang digunakan dalam setiap produk, tape menaon: beras ketan hitam $1 / 2 \mathrm{~kg}$, air bersih 2 gelas, daun pisang sesuaikan, ragi $2 \mathrm{btr}$, gula pasir atau gula halus 2 sendok makan, Rengginang : 2 liter beras ketan hitam, dicuci bersih dan rendam selama kurang lebih 5 jam, minyak goreng $2 \mathrm{~kg}$, air bersih secukupnya, ketumbar $1 / 2$ sendok teh, 3 siung bawang putih, Garam dapur 1 sendok teh, penyedap rasa 5 gram, Dodol ketan hitam : tepung ketan hitam sebanyak 500 gram, tepung beras sebanyak 50 gram, gula merah sebanyak 900 gram, santan kental sebanyak 1 liter, santan cair sebanyak 1 liter, garam sebanyak setengah sendok teh, daun pandan sebanyak 1 lembar, daun pisang, Cengkarok: 250 gram beras ketan, 200 gram gula merah, 1/4 sendok teh garam, $300 \mathrm{cc}$ santan, 1/2 sendok makan air kapur sirih, 3/4 butir kelapa, Brownies : 6 butir telur, 200 gr gula pasir, 1 sdt emulsifier, 1 sdt vanilla, $1 / 4$ sdt garam, 2 sdm susu kental manis, 250 gr tepung ketan hitam, 20 gr cokelat bubuk (Coklat bubuk dan tepung ketan hitam dicampur, lalu diayak), 100gr dark cooking chocolate (dipotong kecil-kecil), $200 \mathrm{ml}$ minyak goreng (mentega yang dilelehkan)

\section{Alat}

Peralatan yang digunakan dalam mengolah seluruh produk dimaksud meliputi: Alat pengaduk kompor gas, panci kukusan, baskom, pisau, talenan, nyiruk, sealer, cup kemasan, kuali penggorengan, plastik kemas, serbet, gelas literan, timbangan, mixer, oven, tirisan, sendok goreng, toples, tisu, loyang alumunium, celemek, sarung tangan plastik, ayakan, loyang,ayakan 80 mesh, kain saring, spatula dan blender.

\section{Aspek proses produksi olahan Pengolahan tape menaon}

Dibersihkan terlebih dahulu beras ketan hitam Kemudian direndam beras ketan hitam selama 1 malam agar teksturnya lebih empuk, diangkat dari rendaman kemudian ditiriskan, beras ketan hitam kemudian di kukus hingga setengah matang, disiapkan air yang panas 2 gelas. Pasa saat di kukus setelah mengeluarkan uap panas kemudian 
atasnya siram dengan air panas 2 gelas tersebut dan posisi masih berada di atas kompor. Sambil di aduk-aduk agar air panasnya tercampur merata, dikukus kembali hingga matang, diangkat dan ditambahkan ke wadah yang besar seperti nampan kemudian diratakan dan didiamkan sampai dingin, kemudian dialasi dengan daun pisang sampai rapih. Dimasukkan lapisan pertama beras ketan dan taburi dengan ragi hingga merata. Untuk lapisan yang kedua beras ketan, ditaburi kembali dengan ragi dan gula halus. Untuk menutupi permukaan gunakan daun pisang sebanyak 2 lapis dan akhirnya di bantu dengan kain yang bersih sebagai penutupnya. Didiamkan beras ketan selama 3 hari 2 malam, dan disimpan wadah bakal tape tersebut di ruangan yang hangat.

\section{Pengolahan rengginang}

Bawang putih, garam dapur, ketumbar dan penyedap rasa dihaluskan, Selanjutnya dimasukkan beras ketan ke dalam kukusan dan dikukus selama kurang lebih 10 menit, kemudian di angkat beras dan dicampurkan dengan bumbu yang telah dihaluskan sambil diaduk, setelah itu dituangkan kurang lebih $500 \mathrm{ml}$ air panas, diaduk kembali, dimasukkan kembali ke dalam kukusan dan dikukus selama kurang lebih 25 menit atau hingga matang, dibentuk menjadi bulatan yang pipih. Lalu dijemur hingga benar benar kering selama kurang lebih 3 hari, bila sudah kering, digoreng.

\section{Pengolahan cengkarok}

Direndam beras ketan semalaman, ditiriskan, disangrai dan ditumbuk kasar. Gula merah dan santan dididihkan, dimasukkan ketan sangrai, garam di masak sambil di aduk hingga rata dan kering . Adonan dituang di loyang

\section{Pengolahan dodol}

Santan kental di didihkan bersama daun pandan, gula merah, serta garam, tepung ketan dilarutkan bersama santan yang encer sampai merata, lalu dituangkan ke dalam didihan santan kental sedikit-sedikit, lalu diaduk terus menerus hingga merata, Selanjutnya adonan dituangkan kepada loyang yang sudah dialasi dengan menggunakan daun pisang, diratakan, kemudian didinginkan.

Pengolahan brownies

Dipanaskan kukusan dengan api sedang, dilelehkan dark cooking chocolate, dimasukkan minyak goreng atau mentega yang telah dilelehkan, kemudian diaduk rata. Lalu di dinginkan. Selanjutnya dikocok telur, gula pasir, emulsifier \& garam menggunakan mixer dengan kecepatan tinggi hingga mengembang, berwarna putih dan kental, ditambahkan vanilla, diaduk rata, kemudian ditambahkan susu kental manis, diaduk rata. Selanjutnya dimasukkan campuran coklat bubuk dan tepung ketan hitam sedikit demi sedikit sambil terus dikocok dengan mixer kecepatan rendah hingga adonan merata, dimasukkan campuran dark cooking chocolate dan minyak goreng/ mentega cair, di aduk dengan spatula hingga merata, dituang adonan ke dalam loyang berukuran 20x20x7 cm yang telah dialasi kertas roti dan diolesi margarin. Adonan dalam loyang dikukus selama 25-30 menit hingga matang.

\section{HASIL DAN PEMBAHASAN}

Produk olahan dari beras ketan hitam diuji tingkat kesukaannya terhadap seluruh peserta pelatihan dengan tujuan untuk mengetahui daya terima sebelum produk dipasarkan. Hasil penilaian peserta disajikan pada Tabel 1.

Tabel 1. Olahan beras ketan hitam

\begin{tabular}{lcc}
\hline \multirow{2}{*}{ Nama Produk } & \multicolumn{2}{c}{ Penilaian Konsumen } \\
\cline { 2 - 3 } & Menerima & Tidak Menerima \\
\hline Tape menaon & 18 & 2 \\
dodol & 15 & 5 \\
Cengkarok & 16 & 4 \\
Brownies & 20 & 0 \\
Rengginang & 20 & 0 \\
\hline
\end{tabular}

Sumber data: Kuisioner Kegiatan PKM 2019 


\section{Tape menaon}

Produk tape menaon dapat diterima oleh seluruh peserta pelatihan dari sisi penerimaan rasa, aroma. Rasa yang dihasilkan manis, karena proses fermentasi. Warna produk hitam sesuai bahan dan merupakan makanan semi padat. Agar lebih menarik dapat disajikan dalam wadah transparan atau menggunakan daun.

\section{Cengkarok}

Produk cengkarok diminati oleh 16 dengan total 20 responden, artinya tidak semua memberikan penilaian terhadap produk yang dihasilkan. Menurut konsumen yang tidak menyukai produk ini disebabkan karena tampilan yang kurang menarik namun cukup digemari.

\section{Dodol ketan hitam}

Dodol ketan hitam disukai oleh 15 orang dan 5 orang tidak menyukai. Penilaian suka didasarkan atas rasa, dan tekstur. Rasa yang diperoleh manis. Kelemahannya produk ini relative lengket Karena kandungan amilosa dan amilopektin yang dimiliki, sehingga mengkonsumsinya agak rumit.

\section{Brownies}

Brownies disukai oleh seluruh responden. Alasan ketertarikan responden adalah rasa dan tekstur karena ada kombinasi dengan dark chocolate.

\section{Rengginang}

Rengginang merupakan makanan yang ringan dan tekstur renyah yaitu $100 \%$ responden menyukai produk ini. Responden menyukai produk ini karena renyah dan dapat dijadikan camilan ringan serta tidak mengenyangkan.

Berbagai aktivitas kegiatan PKM dan proses produksi dapat dilihat pada Gambar 1, Gambar 2, Gambar 3, Gambar 4 dan Gambar 5.
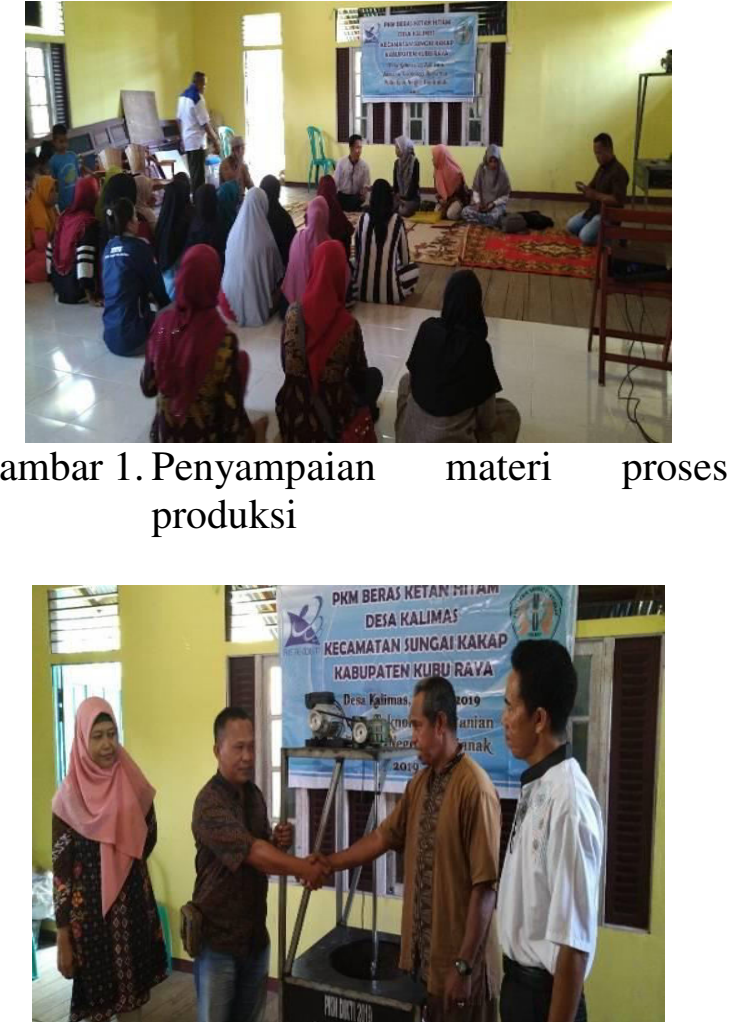

Gambar 2. Kegiatan serah terima alat

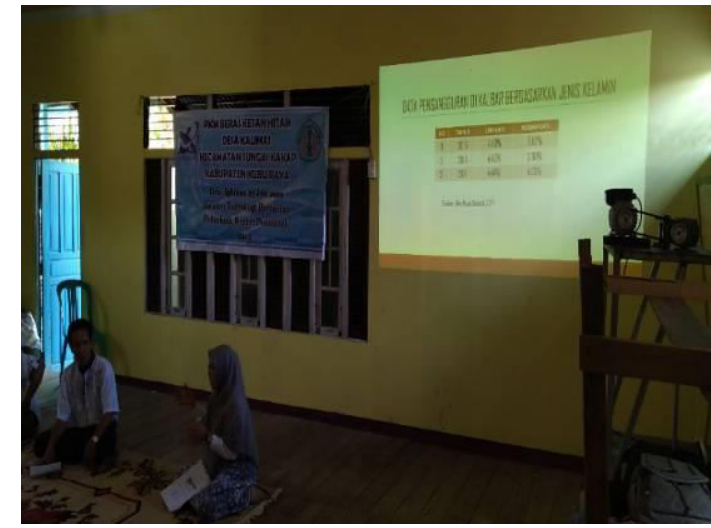

Gambar 3. Penyampaian materi tentang pemasaran

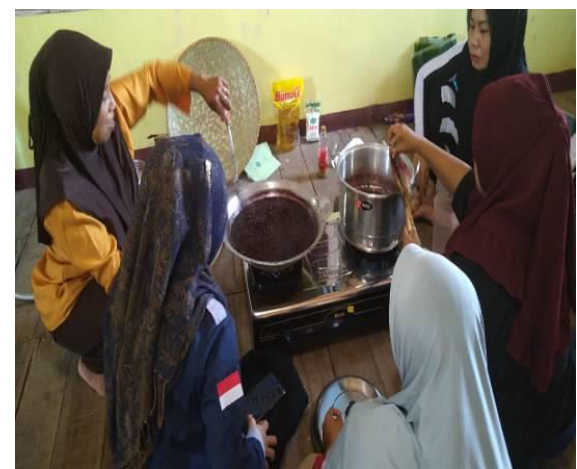

Gambar 4. Kegiatan proses produksi oleh Mitra 


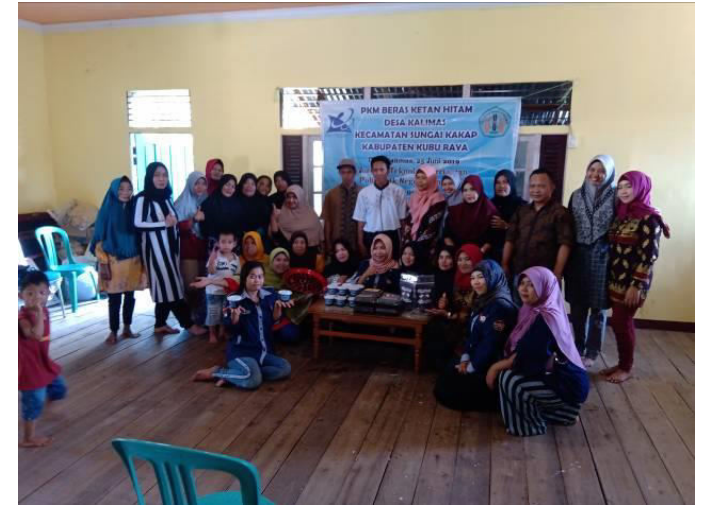

Gambar 5. Mitra dan produk olahan dari beras ketan hitam

\section{KESIMPULAN}

1. Kelompok tani sebagai mitra dapat mengolah pangan berbahan beras ketan hitam dengan hasil yang baik dan menarik sehingga memiliki keterampilan dan keahlian dalam pengembangan lanjutan usaha yang dimaksud.

2. Produk yang memiliki penerimaan $100 \%$ adalah brownies dan rengginang karena lebih enak dan ringan.

\section{UCAPAN TERIMAKASIH}

Kesempatan ini kami tim pelaksana kegiatan mengucapkan terima kasih kepada KEMENRISTEKDIKTI yang telah membiayai seluruh kegiatan Program Kemitraan Masyarakat tahun anggaran 2019 dan terima kasih juga kepada warga Desa Kalimas, sehingga kegiatan ini berlangsung dengan baik dan lancar.

\section{DAFTAR PUSTAKA}

Abdel-Aal, E. S. M., Young, J. C., \& Rabalski, I. (2006). Anthocyanin composition in black, blue, pink, purple, and red cereal grains. Journal of Agricultural and Food Chemistry, 54(13), 4696-4704.

Adom, K. K., \& Liu, R. H. (2002). Antioxidant activity of grains. Journal of Agricultural and Food Chemistry, 50(21), 6182-6187.

Ali, T., Lam, D., Bronze, M. S., \& Humphrey, M. B. (2009). Osteoporosis in inflammatory bowel disease. The American Journal of Medicine, 122(7), 599-604.

Aprin, G. (2012). Kubu raya kite. Retrieved from: http://kubu-rayakite.blogspot.com/p/potensipangan.html

Bertoldi, F.C. (2014). Osteoporosis in gastrointestinal diseases. Translational Gastrointestinal Cancer, 4(1), 57-68.

Dipti, S. S., Bergman, C., Indrasari, S. D., Herath, T., Hall, R., Lee, H., ... \& Fitzgerald, M. (2012). The potential of rice to offer solutions for malnutrition and chronic diseases. Rice, 5(1), 16.

Jang, W. S., Seo, C. R., Jang, H. H., Song, N. J., Kim, J. K., Ahn, J. Y., ... \& Park, K. W. (2015). Black rice (Oryza sativa L.) extracts induce osteoblast differentiation and protect against bone loss in ovariectomized rats. Food \& Function, 6(1), 264-274.

Kim, C., Kikuchi, S., Kim, Y., Park, S., Yoon, U., Lee, G., .. \& Park, S. (2010). Computational identification of seed-specific transcription factors involved in anthocyanin production in black rice. BioChip Journal, 4(3), 247255.

Kim, S. Y., Kim, Y. J., An, Y. J., Lee, H. J., Lee, S. H., Kim, J. B., ... \& Lee, S. J. (2016). Black rice (O ryza Sativa, $H$ eukmi) extracts stimulate osteogenesis but inhibit adipogenesis in mesenchymal C3H10T $\quad 1 / 2$ cells. Journal of Food Biochemistry, 40(2), 235-247.

Kong, L., Wang, Y., \& Cao, Y. (2008). Determination of Myo-inositol and Dchiro-inositol in black rice bran by capillary electrophoresis with electrochemical detection. Journal of Food Composition and Analysis, 21(6), 501-504.

Lai, L. R., Hsieh, S. C., Huang, H. Y., \& Chou, C. C. (2013). Effect of lactic fermentation on the total phenolic, saponin and phytic acid contents as well as anti-colon cancer cell proliferation activity of 
soymilk. Journal of Bioscience and Bioengineering, 115(5), 552-556.

Lee, J. H. (2010). Identification and quantification of anthocyanins from the grains of black rice (Oryza sativa L.) varieties. Food Science and Biotechnology, 19(2), 391-397.

Pemerintah Desa Kalimas. (2013). Profil Desa Kalimas. Retieved from: http://kalimasraya.blogspot.com/2013/ 07/profil-desa-kalimas.html

Samyor, D., Das, A. B., \& Deka, S. C. (2017). Pigmented rice a potential source of bioactive compounds: a review. International Journal of Food Science \& Technology, 52(5), 10731081.

Şanlier, N., Gökcen, B. B., \& Sezgin, A. C. (2019). Health benefits of fermented foods. Critical Reviews in Food Science and Nutrition, 59(3), 506-527.

Schmidt, C. G., Gonçalves, L. M., Prietto, L., Hackbart, H. S., \& Furlong, E. B. (2014). Antioxidant activity and enzyme inhibition of phenolic acids from fermented rice bran with fungus Rizhopus oryzae. Food Chemistry, 146, 371-377.

Suhartatik, N., Karyantina, M., Mustofa, A., Cahyanto, M.N., Raharjo, S., \& Rahayu, E.S. (2013). Stabilitas ekstrak antosianin beras ketan (oryza sativa var. glutinosa) hitam selama proses pemanasan dan penyimpanan. Agritech, 33(4).

Weaver, C. M. (2015). Diet, gut microbiome, and bone health. Current Osteoporosis Reports, 13(2), 125-130. 